\section{FRI0133 OUTCOME AND PROGNOSTIC FACTORS FOR LUPUS NEPHRITIS IN SLE PATIENTS TREATED WITH "SMALL PULS" OF CYCLOPHOSPHAMIDE: FOLLOW-UP STUDY 1985-1999}

RM Stojanovic, D Gacic, D Palic-Obradovic, R Blagojevic-Lazic, G Susic, N Damjanov, G Stevanovic, V Mircetic, M Jeftic, M Budimir. Clinical Department VI, Institute of Rheumatology-Belgrade, Belgrade, Yugoslavia

\subsection{6/annrheumdis-2001.168}

Background In the period 1985-1999, at the Institute of Rheumatology in Belgrade on clinical ward VI, 398 patients with SLE were treated. The most of SLE patients with major systems affected (lupus nephritis-LN, Lupus CNS and serious haematological manifestations) were treated with cyclophosphamide (Cy), some of them with "small puls"-spCy. ${ }^{1}$ Renal function was demaged in 120 of 389 (30\%) patients. Our previous experience of LN treatment with spCy was reported. ${ }^{2}$

Objectives To evaluate the effect of SLE treatment with "small puls" doses of Cy on lupus nephritis and estimation of prognostic factors for outcome of renal damage.

Methods In the follow up study the data on the effects of the treatment with spCy in 41 female patients were evaluated. "Small pulse"Cy treatment schema was established as: $400 \mathrm{mg}$ $\mathrm{Cy}$ in iv infusion in a volume of $150 \mathrm{ml}$ sol. $5 \%$ glucose during 30 min, weekly for three months, than in two or three weeks period for three months. The next treatment was once in a month during few months or years. The average age of SLE patients at the start of the disease was 27.7 yr., time from the first symptoms to the diagnose was 12.3 months and duration of the disease $9.24 \mathrm{yr}$. The kidney biopsy in 13 patients (one biopsy repeated) according to the WHO classification class revealed. Duration of treatment with spCy was 19.26 months with average total dose of $11.6 \mathrm{~g}$. Short time discontinuation of the treatment was in 6 pts. Therapy was discontinuated in one pts. during serious infection.

Results The outcome of LN treatment in 28 (68.3\%) patients was satisfactory (remission, mild activity of disease) and in 13 patients unsatisfactory (moderate activity in two, severe activity in three, chronic renal insufficiency in two, hemodyalisis was essential in four and two patients died). One of two patients died after self-discontinuation of SEL therapy and later development of acute renal failure during infection. The patients with unsatisfactory results were younger at the beginning of the disease; the renal damage appeared earlier during SLE. At the beginning of the therapy they had more frequently increased creatinine level and frequently hypertension. In the group with satisfactory outcome renal biopsy was more frequently performed, and therefore treatment with spCy was started earlier in $\mathrm{LN}$ and lasted longer

Conclusion According to our results the better prognosis in SLE patients treated with spCy was obvious if the $\mathrm{LN}$ was early detected using renal biopsy, if treatment started in early phase of $\mathrm{LN}$ and if it lasted long enough. Classic puls therapy with $\mathrm{Cy}^{3}$ should be reserved for younger patients with increased level of creatinine in early stage of LN, and with renal hypertension.

\section{REFERENCES}

1 Budimir $\mathrm{M}$, et al. XVIth International Congress of Rheumatology, Abstract Book Sidney, 1985;105:F74

2 Stojanovic R, et al. Clin Exp Rheumatol. 1996;14:S16-S50

3 Boumpas DT, Austin HA, Vaughn E, et al. Lancet 1992:340:741-5

\section{FRI0134 SHRINKING LUNG SYNDROME AS A CLINICAL MANIFESTATION OF PATIENTS WITH SLE: 5 CASES REPORT}

J Gratacós, E Naval, M Larrosa, CH Domingo, M Bosque, C Tolosa, E Casado, A Marín. Rheumatology Unit, University Hospital C.S.P.T., Sabadell, Spain

\subsection{6/annrheumdis-2001.169}

\section{Background}

Objectives To describe the clinical manifestations and pulmonary function tests (PFTs) of 5 patients with SLE and shrinking lung syndrome (SLS).

Methods 5 patients $(3 \mathrm{~F} / 2 \mathrm{M})$ with an age range between $11-76$ years. Rewiew of clinical manifestations; laboratory testing (hemogram, antinuclear antibodies, rheumatoid factor-RF- and muscular enzimes); PFTs; X-rays; thoracic CT scan; treatment and follow-up.

Results SLR was detected 2 months to 20 years after the diagnosis of SLE. All cases were ANA and AntiDNA positives and quiescent disease. Only one patient had visceral manifestations (nephropathy). The SLEDAI score ranged between 6 and 13 . Poliarthritis was present in two cases (erosive in one) with RF negative. Dispnea was the manifestation which led lo SLS diagnosis with no clinical or laboratory evidence of peripheral miopathy. PTFs showed: FVC $1954 \pm 563 \mathrm{ml}(65.4 \pm 15.4 \%)$, FEV1 $1562 \pm 384 \mathrm{ml}(69.8 \pm 15 \%)$, FEV1/FVC $81.4 \pm 7.2 \%$, TLC $3400 \pm 1032 \mathrm{ml}(68 \pm 10 \%), \mathrm{RV} 1148 \pm 626 \mathrm{ml}(59 \pm$ $17.6 \%)$, DLCO $13.2 \pm 3.4 \mathrm{ml} / \mathrm{min} / \mathrm{mmHg}(60.6 \pm 17.9 \%)$, KCO $4.4 \pm 2.2(86.2+/ 15.9 \%)$, MIP $59.5 \pm 17.5 \mathrm{cmH}_{2} \mathrm{O}(77$ $\pm 21 \%)$, MEP $88.7 \pm 25.4 \mathrm{cmH} 2 \mathrm{O}(97.7 \pm 16 \%), \mathrm{PaO} 286.5$ $\pm 4.3 \mathrm{mmHg}, \mathrm{PaCO} 226.4 \pm 14.7 \mathrm{mmHg}$, Aa gradient $17 \pm 8$. Radiological studies showed reduced lung size with no parenchimal disease. MIP was impaired in two patients at 3 and 24 months from SLS diagnosis. All patients were treated with corticosteroids (4-20 mg/day). Theophilin $(10 \mathrm{mg} / \mathrm{kg} / \mathrm{day})$ was added to one patient. No effective responsiveness was detected on the follow-up ( 2 to 24 months).

Conclusion All patients with SLS met 4 or more revised ARA criteria of SLE. Dispnea was the main clinical manifestation at SLS onset. Characteristically, SLS presented with restrictive PFTs without parenchimatous disturbances. Treatment response was ineffective and functional and clinical stabilitation was the rule on follow-up.

\section{FRI0135 PREDICTIVE VALUE OF THE INDUCED SPUTUM CYTOLOGY IN PATIENTS WITH PULMONARY INVOLVEMENT IN SYSTEMIC CONNECTIVE TISSUE DISEASES}

${ }^{1} \mathrm{P}$ Bradna, ${ }^{2} \mathrm{Z}$ Parakova, ${ }^{1} \mathrm{~B}$ Kral, ${ }^{1} \mathrm{Z}$ Hrncir, ${ }^{1} \mathrm{Z}$ Dvorak, ${ }^{1} \mathrm{~T}$ Soukup. ${ }^{2} 2 \mathrm{nd}$ Department of Medicine; ${ }^{2}$ Department of Pulmonary Diseases, University Hospital Hradec Kralove, Hradec Kralove, Czech Republic

\subsection{6/annrheumdis-2001.170}

Background Pulmonary involvement is frequent and serious organ manifestation of connective tissue diseases. Diagnosis needs to use the set of examination procedures. Some of these methods represent stress for patient, others are expensive for repetitive use. Method of induced sputum is simple, non-invasive, reproducible method, measuring intensity of inflammatory reaction in bronchial asthma and interstitial lung disease patients. We have found increased frequency of pulmonary involvement in patients with leucocyte predominance in induced sputum. 
Objectives Aim of current study was to estimate predictive value of cytology of induced sputum for progressive pulmonary involvement in patients with connective tissue diseases.

Methods Forty-five patients with established diagnosis of connective tissue disease (SLE, PSS, PM/DM), were examined for pulmonary involvement (X-ray, spirometry, diffusion lung capacity, high resolution CT scan, event.bronchoscopy with BAL). Induced sputum was obtained after inhalation of $5 \mathrm{ml}$ of 3 percent solution of natrium chloride by ultrasonographic nebuliser. The induced sputum was cultivated, cytological and immunophenotypisation examinations were made. Pulmonary function tests and induced sputum examinations were repeatedly done after 9-12 moths.

Results We have detected progression of pulmonary involvement in 16 patients Cytological features of leucocyte predominance were found in 12 of them. In 29 non-progressive patients was leucocyte predominance found in only six cases. Respiratory infection was excluded.

Conclusion Method of induced sputum seems, after thoroughgoing appreciation, to be the interesting possibility of simple, non-invasive method for screening of pulmonary involvement progression in patients, suffering by connective tissue diseases.

\section{REFERENCES}

1 Olivieri $D$, Dlppolito $R$, Chetta A. Induced sputum: diagnostic value in interstitial lung disease. Curr Opin Pulm Med. 2000;6(5):411-14

2 Bradna $P$, Parakova $Z$, Kral $B$, Hrncir $Z$, et al. Method of induced sputum in screening of pulmonary involvement in connective tissue diseases. Rheumatologia 2000;14(2):91

\section{FRI0136 IMMUNE ADSORPTION IN HIGHLY ACTIVE SLE INCREASES THE RISK OF BACTERIAL, BUT NOT OF SEVERE VIRAL INFECTIONS}

${ }^{1} \mathrm{GH}$ Stummvoll, ${ }^{1} \mathrm{M}$ Aringer, ${ }^{2} \mathrm{M}$ Jansen, ${ }^{2} \mathrm{~A}$ Goldammer, ${ }^{2} \mathrm{~K}$ Derfler, ${ }^{1} \mathrm{JS}$ Smolen, ${ }^{1}$ WB Graninger. ${ }^{1}$ Rheumatology/Internal Medicine III; ${ }^{2}$ Nephrology/Internal Medicine III, University of Vienna, Vienna, Austria

\subsection{6/annrheumdis-2001.171}

Background Active SLE patients undergoing plasmapheresis and cyclophosphamid therapy are at high risk of severe bacterial and viral infections. Immune adsorption (IAS) is a more novel approach to autoantibody removal with an unclear risk of infections in SLE.

Objectives We therefore decided to investigate the risk of infections in patients undergoing longterm IAS.

Methods We analysed the records of ten consecutive active SLE patients treated with long term IAS (mean 38 months) for the occurrence of severe infectious disease. We compared the IAS patients to historical control groups ${ }^{1}$ of 9 patients under plasmapheresis and cyclophosphamid (PP) and 12 patients treated with cyclophosphamid (CX) alone for similar time periods.

Results One IAS patient died from gram-negative septicemia. Three localised bacterial infections (two gram-positive, one gram-negative) were treated with antibiotics. All infections occurred in the subgroup of five highly active patients (SIS $>15$, mean $17.7 \pm 0.9$ ) who all underwent additional CX therapy, showing characteristics similar to the CX and PP control groups (SIS $18.7 \pm 2.4$ and $20.3 \pm 3.7$, respectively). Bacterial infections were more frequent than in the CX group (4/5 vs $1 / 12$, p $<0.01$ ), but similar to the PP group. No severe viral infections were detected.
Conclusion IAS did not promote severe viral infections, but was associated with an increased rate of potentially life-threatening bacterial infections in SLE patients with very active disease.

\section{REFERENCE}

1 Aringer M, Smolen JS, Graninger WB. Severe infections in plasmapheresis-treated systemic lupus erythematosus. Arthritis Rheum. 1998;41(3):414-20

\section{FRI0137 PROLACTIN IN SYSTEMIC LUPUS ERYTHEMATOSUS}

${ }^{1}$ L Moszkorzova, ${ }^{1} \mathrm{C}$ Dostal, ${ }^{2} \mathrm{~J}$ Marek, ${ }^{2} \mathrm{Z}$ Lacinova, 'L Musilova. ${ }^{1} 1$ st Department, Institute of Rheumatology, Prague, Czech Republic, ${ }^{2} 3 r d$ Med. Department, 1st Med. Faculty Charles University, Prague, Czech Republic

10.1136/annrheumdis-2001.172

Background Prolactin (PRL) is an anterior pituitary hormone which is known to stimulate humoral and cell mediated immune responses, and may have a role in the pathogenesis of systemic lupus erythematosus (SLE).

Objectives To determine whether elevated serum prolactin associates the SLEDAI activity and/or specific organ involvement in SLE when recent reports have been till now discrepant.

Methods Basal serum PRL levels were determined in 55 consecutive SLE patients (pts) (49 females, 6 males) and in 41 healthy controls (31 females, 10 males) by RIA method. The estimated normal values of serum PRL were $200 \mathrm{mUI} / \mathrm{l}$ for males and 450 $\mathrm{mUI} / \mathrm{l}$ for females.

Results The idiopathic hyperprolactinemia (hyper-PRL) was found in 7 SLE females $(14,29 \% ; 828,682 \pm 391,410 \mathrm{mUI} / \mathrm{l})$ and in 3 males $(50,00 \% ; 305,469 \pm 65,751 \mathrm{mUI} / \mathrm{l})$; and in one male in healthy controls $(10,00 \% ; 348,352 \mathrm{mUI} / \mathrm{l})$ only. In remaining 42 SLE females and in 3 males PRL serum level was normal $(365,783 \pm 282,796 \mathrm{mUI} / \mathrm{l} ; 142,854 \pm 84,512 \mathrm{mUI} / \mathrm{l})$. After 6 months repeatedly determined serum PRL in 2 females and 2 males with initial hyper-PRL, has shown normalisation in 1 female and 1 male. As to the proposed association between hyper-PRL and disease activity and specific organ involvement and presence of anti-ds-DNA there are some data on the Table 1.

\begin{tabular}{llllll}
\multicolumn{7}{l}{ Abstract FRI0137 Table 1 } & & \\
\hline & Hyper-PRL & SLEDAI activity $>4$ & $\begin{array}{l}\text { Lupus nephritis } \\
(\mathbf{n}=15)\end{array}$ & $\begin{array}{l}\text { CNS } \\
(\mathbf{n}=11)\end{array}$ & $\begin{array}{l}\text { anti-ds-DNA } \\
(\mathbf{n}=28)\end{array}$ \\
\hline Females & $7(14 \%)$ & $5(71 \%)$ & $3(20 \%)^{*}$ ns & $0{ }^{*} \mathrm{~ns}$ & 3 \\
Males & $3(50 \%)$ & 2 & 3 & 1 & 2 \\
\hline
\end{tabular}

Conclusion There was significantly higher frequency of hyperPRL in 55 SLE pts compared to 41 healthy controls ( $p<$ 0,001). The value of serum PRL has normalised in 2 pts with hyper-PRL from 4 pts with initial hyper-PRL without any specific treatment after 6 months by repeated estimation. We document a new idiopathic hyper-PRL in 1 patient with normal initial serum PRL. The association between hyper-PRL and activity and/or specific organ involvement and presence of anti-dsDNA was not statistically significant due to low number of observations.

\section{REFERENCES}

1 Walker SE, et al. Effect of prolactin in stimulating disease activity in SLE. Proc NY Acad Sci 1998:840:762-72 